\title{
Safety and tolerability of antipsychotics: focus on amisulpride
}

This article was published in the following Dove Press journal:

Drug, Healthcare and Patient Safety

30 September 2010

Number of times this article has been viewed

\author{
Mario F Juruena' \\ Eduardo Pondé de Sena ${ }^{2}$ \\ Irismar Reis de Oliveira ${ }^{3}$ \\ 'Stress and Affective Disorders \\ Programme, Department of \\ Neuroscience and Behaviour, Faculty \\ of Medicine of Ribeirao Preto, \\ University of Sao Paulo, Sao Paulo, \\ Brazil; ${ }^{2}$ Department of Pharmacology, \\ Institute of Health Sciences, Federal \\ University of Bahia, Salvador: \\ ${ }^{3}$ Department of Neurosciences and \\ Mental Health, School of Medicine, \\ Federal University of Bahia, Salvador, \\ BA, Brazil
}

Correspondence: Mario F Juruena Stress and Affective Disorders Programme, University of Sao Paulo, Saude Mental- USP, Rua Catao Roxo, 2650, Ribeirao Preto, Sao Paulo, CEP | 405 |- | 40, Brazil

$\mathrm{Tel}+55|63630796|$

$\mathrm{Fax}+55163630796 \mid$

Email juruena@fmrp.usp.br
Abstract: The introduction of the atypical antipsychotic drugs represents an important advance in the treatment of schizophrenia, because the therapeutic efficacy, tolerability, and safety profiles of these agents seem to be superior to that of the classical neuroleptics. As would be predicted from the pharmacologic profile of a pure $\mathrm{D}_{2} / \mathrm{D}_{3}$ receptor blocker, amisulpride is an atypical antipsychotic agent, effective for positive and negative symptoms, which can bring about additional improvement in the social functioning and quality of life of patients with schizophrenia. Amisulpride is effective in acute schizophrenia as determined by Clinical Global Impression scores. The major concern regarding the safety of the atypical antipsychotics is related to their propensity to induce weight gain and alter glucose and lipid metabolism. Amisulpride has one of the lowest potentials for weight gain of all the antipsychotic agents, and is associated with clearly lower use of antiparkinsonian medication and with fewer dropouts due to adverse events than conventional antipsychotics. Amisulpride is well tolerated with regard to anxiety and insomnia, and not notably different from placebo. Amisulpride has a pronounced prolactin-elevating effect which appears to be independent of dosage and duration of administration. Hyperprolactinemia rapidly reverses following amisulpride discontinuation. Amisulpride benefits patients with negative symptoms, and is the only antipsychotic to demonstrate efficacy in patients with predominantly negative symptoms. Amisulpride maintains its efficacy when used for medium/ long-term treatment, as demonstrated in studies of up to 12 months. In terms of relevance of the effects, superiority is observed for quality of life, social adaptation, and functioning, as measured by the Quality of Life and Functional Status Questionnaire scales. In conclusion, amisulpride is an antipsychotic agent with proven efficacy and good tolerability. Moreover, this drug can help people with schizophrenia to attain social reinsertion.

Keywords: amisulpride, antipsychotic agents, safety, adverse events, tolerability

\section{Introduction}

Nowadays, new treatments for schizophrenia are more ambitious, aiming to improve not only psychotic symptoms, but also quality of life and social reinsertion. We briefly but critically outline advances in the treatment of schizophrenia from the mid-1970s up to the present. For many years, it was widely accepted that any effective drugs for schizophrenia would also induce extrapyramidal side effects (EPS), and the term "neuroleptic" was originally used to describe such neurologic side effects. However, adverse effects, such as movement disorders and sedation, are problematic and can result in noncompliance with medication. Positive symptoms, such as delusions, hallucinations, and thought disorders, are more often experienced in the acute phases of the illness than are negative symptoms, such as poverty of 
speech, lack of motivation, apathy, and inability to express emotions. ${ }^{1}$ However, negative symptoms are probably the more disabling, and may not respond as well to typical antipsychotic drugs. In addition to efficacy issues, safety of medication also influences the choice of antipsychotic agent. Atypical antipsychotic drugs, by definition, differ from typical antipsychotic agents in producing significantly fewer EPS and carrying a lower risk of tardive dyskinesia in vulnerable clinical populations at doses that result in comparable control of psychosis. Effects on neuronal survival and plasticity, together with decreased neurotoxicity, might also contribute to their clinical advantages over typical neuroleptic drugs. ${ }^{2}$

\section{Pharmacologic profiles of atypical antipsychotics}

The atypical drugs differ from the typicals in their mechanism of action, but not all share the same mechanism (Tables $1 \& 2$ ). Clozapine, the prototype of these agents, has been found to improve delusions and hallucinations in patients who fail to respond to other antipsychotic drugs, and to reduce the risk of suicide. These agents have been found to increase cortical dopamine and acetylcholine release, as well as to have a variety of effects on the glutamatergic system not shared by the typical agents. ${ }^{2}$ The term "atypical" was then accepted as including the characteristics common to those antipsychotic drugs developed more recently, including absence of hyperprolactinemia, greater efficacy in treating positive and negative symptoms as well as symptoms of disorganization, and absence of tardive dyskinesia or dystonia after being administered chronically., At least in clinical circles, most would agree that clozapine, risperidone, olanzapine, quetiapine, sertindole, ziprasidone, aripiprazole, and amisulpride are atypical, even though many of those agreeing to the above list may disagree on the criteria of definition. When compared with older antipsychotic drugs, atypical antipsychotics show fewer EPS and require less concomitant anticholinergic use, even when controlling for the high doses of haloperidol that have been conventionally used in such studies. ${ }^{5}$

The second most commonly shared feature is that most of the newer atypical antipsychotics show either no, or only transient, prolactin elevation. The two notable exceptions in this regard are risperidone and amisulpride, and it is now understood that this exception may largely be attributed to these drugs having a higher peripheral/central distribution ratio, thereby leading to excessive dopamine blockade in the pituitary that lies outside of the blood-brain barrier. ${ }^{6}$

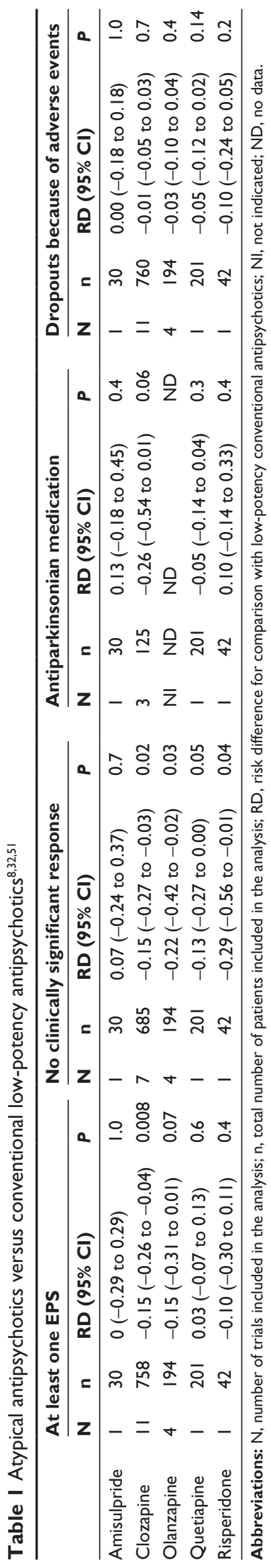


Conventional antipsychotics continue to be the first choice when just cost of treatment is considered, which remains important in poor regions. It is likely that the next generation of treatments will have to move beyond reliance on a single drug as the sole treatment for the multidimensional characteristics of schizophrenia. Most new antipsychotics introduced onto the market in the past two decades (eg, risperidone and olanzapine) have been multireceptor-acting agents, especially having concomitant 5- $\mathrm{HT}_{2}$ receptor antagonism. ${ }^{7}$ A notable exception to this has been amisulpride, a benzamide derivative that has high and similar affinities for the dopamine $\mathrm{D}_{2}$ and $\mathrm{D}_{3}$ receptor subtypes and is devoid of any significant affinity to other receptor systems. ${ }^{8}$ Yet, amisulpride shows most of the attributes of atypicals, ie, a lower risk of EPS, a somewhat greater improvement in positive and negative symptoms, and better overall outcome in longer-term follow-up studies compared with more conventional serotonin-dopamine or multireceptor atypical antipsychotics., ${ }^{9} 10$

Amisulpride is a highly selective dopamine $\mathrm{D}_{2}$-like receptor antagonist $\left(\mathrm{Ki}=2.8 \mathrm{nmol} / \mathrm{L}\right.$ for $\mathrm{D}_{2}$ receptors and $\mathrm{Ki}=3.2 \mathrm{nmol} / \mathrm{L}$ for $\mathrm{D}_{3}$ receptors), with several orders of magnitude higher affinity for $\mathrm{D}_{2} / \mathrm{D}_{3}$ receptors than any other receptor population. ${ }^{8}$ A positron emission tomography study of amisulpride-treated patients found no significant binding to 5-HT ${ }_{2 \mathrm{~A}}$ receptors. ${ }^{10}$ In clinical trials, amisulpride has shown therapeutic benefit, with a profile of side effects similar to that of placebo. ${ }^{9}$ This and its highly specific receptor profile make it ideally suited to test whether antipsychotic efficacy and a low incidence of EPS may be achieved purely by selective action at limbic cortical dopamine $\mathrm{D}_{2} / \mathrm{D}_{3}$ receptors in vivo. ${ }^{11}$

Some meta-analyses have identified clozapine, amisulpride, risperidone, and olanzapine as being significantly more effective than first generation (typical) antipsychotics and other second-generation (atypical) antipsychotics. ${ }^{10-12}$ Clinically, amisulpride is characterized by a side effect profile most resembling that of an atypical antipsychotic due to its low EPS burden. ${ }^{9}$ However, like risperidone and first-generation antipsychotic drugs, amisulpride causes large elevations in serum prolactin levels, most likely due to its potent $\mathrm{D}_{2} / \mathrm{D}_{3}$ antagonist properties. ${ }^{13}$ Thus, despite having a pharmacologic profile reminiscent of a typical antipsychotic in that it exhibits high D2 affinity and low 5- $\mathrm{HT}_{2 \mathrm{~A}}$ affinity, amisulpride therapeutically resembles atypical antipsychotics. The identification of the $5-\mathrm{HT}_{7 \mathrm{a}}$ receptor as a target blocked by amisulpride suggests a plausible explanation for its antidepressant efficacy. Changes in $5-\mathrm{HT}_{7}$ receptor function have been shown to result from chronic antidepressant treatment. ${ }^{14,15}$ The $5-\mathrm{HT}_{7 \mathrm{a}}$ receptor antagonism, and not $\mathrm{D}_{2} / \mathrm{D}_{3}$ receptor antagonism, likely underlies the antidepressant actions of amisulpride. ${ }^{16}$ Moreover, 5- $\mathrm{HT}_{7}$ receptor antagonists and presently approved antidepressants also appear to have similar effects on hippocampal neurogenesis. ${ }^{17}$

\section{Amisulpride: Safety and tolerability}

Patients with schizophrenia have been found to have increased somatic morbidity and mortality risks relative to the general population. ${ }^{18,19}$ Weight gain might contribute to their risk of morbidity and mortality by leading to an increase in lipid dysregulation, hypertension, Type 2 diabetes mellitus, cardiovascular disease, and other related diseases. ${ }^{20,21}$ In addition, being overweight usually leads to lower self-image and self-esteem, decreased quality of life, and social disadvantages, and is associated with medication noncompliance. ${ }^{22-24}$ Recently, metabolic syndrome in patients with schizophrenia has drawn enormous attention from researchers. Previous studies showed that approximately $28.7 \%-60.0 \%$ of patients with schizophrenia-related disorders have metabolic syndrome. ${ }^{25,26}$ Most studies show that the prevalence of metabolic syndrome in patients with schizophrenia or schizophrenia-related disorders is higher than that in the normal population. ${ }^{26,27}$

Choosing the right antipsychotic is one of the most challenging issues when treating schizophrenia. Next to efficacy issues, safety of medication, including subjectively distressing side effects (sedation, hypersalivation or dry mouth, akathisia, sexual dysfunction) with negative medical consequences (weight gain, orthostatic hypotension, diabetes, hyperprolactinemia, corrected QT prolongation) and life-threatening adverse events (agranulocytosis, neuroleptic malignant syndrome), also influence the choice of medication. ${ }^{28,29}$

"Atypical" is a term widely used to describe some antipsychotics with specific characteristics, such as minimal risk of acute and chronic movement disorders and less sedation..$^{30}$ The atypical antipsychotic drugs are also thought to be more effective than conventional drugs in the treatment of negative symptoms in schizophrenia, although this has not yet been adequately established. ${ }^{31}$ At present, new antipsychotics are routinely investigated for their possible effect on negative symptoms. In spite of their better tolerability profile, CATIE (the Clinical Antipsychotic Trials of Intervention Effectiveness) showed a high dropout rate with atypical antipsychotics because of either inefficacy or intolerable side effects. ${ }^{32}$ The atypical antipsychotic drugs 
Table 2 Relative affinities of antipsychotic drugs at some neurotransmitter receptors relevant to metabolic side effects ${ }^{8,32,51}$

\begin{tabular}{|c|c|c|c|c|c|c|c|c|c|}
\hline $\begin{array}{l}\text { Dopamine } \\
\text { D2 Ki (nM) }\end{array}$ & $\begin{array}{l}\text { Haloperidol } \\
2.0\end{array}$ & $\begin{array}{l}\text { Clozapine } \\
431\end{array}$ & $\begin{array}{l}\text { Olanzapine } \\
72\end{array}$ & $\begin{array}{l}\text { Risperidone } \\
4.9\end{array}$ & $\begin{array}{l}\text { Paliperidone } \\
9.4\end{array}$ & $\begin{array}{l}\text { Quetiapine } \\
567\end{array}$ & $\begin{array}{l}\text { Ziprasidone } \\
4.0\end{array}$ & $\begin{array}{l}\text { Aripiprazole } \\
0.95\end{array}$ & $\begin{array}{l}\text { Asenupine } \\
1.0\end{array}$ \\
\hline $\begin{array}{l}\alpha \mid A- \\
\text { adrenergic }\end{array}$ & $0.17[12]$ & $\begin{array}{l}270 \\
{[1.6]}\end{array}$ & $\begin{array}{l}0.66 \\
{[109]}\end{array}$ & $\begin{array}{l}\mathbf{0 . 9 8} \\
{[5.0]}\end{array}$ & $\begin{array}{l}3.8 \\
{[2.5]}\end{array}$ & $\begin{array}{l}\mathbf{2 5} \\
{[22]}\end{array}$ & $\begin{array}{l}0.22 \\
{[18]}\end{array}$ & $\begin{array}{l}0.038 \\
{[25]}\end{array}$ & $\begin{array}{l}\text { I.I } \\
{[1,2]}\end{array}$ \\
\hline $\begin{array}{l}\alpha 2 \mathrm{~A}- \\
\text { adrenergic }\end{array}$ & $\begin{array}{l}<10^{-2} \\
{[>1000]}\end{array}$ & $\begin{array}{l}3.0 \\
{[142]}\end{array}$ & $\begin{array}{l}0.24 \\
{[3 \mid 4]}\end{array}$ & $\begin{array}{l}0.032 \\
{[151]}\end{array}$ & $\begin{array}{l}2.0 \\
{[4.7]}\end{array}$ & $\begin{array}{l}0.16 \\
{[3600]}\end{array}$ & $\begin{array}{l}0.025 \\
{[160]}\end{array}$ & $\begin{array}{l}0.012 \\
{[74]}\end{array}$ & [1.3] \\
\hline Histamine & $<10^{-2}$ & 220 & 15 & 0.96 & 1.7 & 76 & 0.031 & 0.032 & 1.3 \\
\hline $\mathrm{HI}$ & {$[>1000]$} & [2.0] & [4.9] & {$[5.2]$} & [5.6] & [7.5] & [130] & [28] & {$[1.0]$} \\
\hline Muscarinic & $<10^{-2}$ & 17 & 1.4 & $<10^{-2}$ & $<10^{-2}$ & 0.29 & $<10^{-2}$ & $<10^{-2}$ & $<10^{-2}$ \\
\hline M3 & {$[>1000]$} & [25] & [5I] & {$\left[>10^{4}\right]$} & {$\left[>10^{4}\right]$} & [1943] & {$[>1000]$} & {$[>1000]$} & {$[>1000]$} \\
\hline 5-HTIA & $\begin{array}{l}<10^{-2} \\
{[>1000]}\end{array}$ & $\begin{array}{l}4.1(a) \\
{[105]}\end{array}$ & $\begin{array}{l}0.036 \\
{[2063]}\end{array}$ & $\begin{array}{l}0.011 \\
{[427]}\end{array}$ & $\begin{array}{l}0.015 \\
{[640]}\end{array}$ & $\begin{array}{l}1.3(a) \\
{[430]}\end{array}$ & $\begin{array}{l}0.053(a) \\
{[76]}\end{array}$ & $\begin{array}{l}0.17 *(a) \\
{[5.6]}\end{array}$ & $\begin{array}{l}0.52(a) \\
{[2.5]}\end{array}$ \\
\hline 5-HTIB & $\begin{array}{l}0.012 \\
{[165]}\end{array}$ & $\begin{array}{l}\text { I.I } \\
\text { [398] }\end{array}$ & $\begin{array}{l}0.14 \\
{[509]}\end{array}$ & $\begin{array}{l}0.091 \\
{[53.6]}\end{array}$ & $\begin{array}{l}0.087 \\
{[109]}\end{array}$ & $\begin{array}{l}0.52 \\
{[1109]}\end{array}$ & $\begin{array}{l}\text { I.0 (a) } \\
{[4.0]}\end{array}$ & $\begin{array}{l}<10^{-2} \\
{[830]}\end{array}$ & $\begin{array}{l}0.33 \\
{[4.0]}\end{array}$ \\
\hline $5-\mathrm{HT} 2 \mathrm{~A}$ & $\begin{array}{l}0.035 \\
{[57]}\end{array}$ & $\begin{array}{l}81 \\
{[5.35]}\end{array}$ & $\begin{array}{l}30 \\
{[3.73]}\end{array}$ & $\begin{array}{l}29 \\
{[0.17]}\end{array}$ & $\begin{array}{l}4.9 \\
{[1.9]}\end{array}$ & $\begin{array}{l}2.8 \\
{[200]}\end{array}$ & $\begin{array}{l}13 \\
{[0.30]}\end{array}$ & $\begin{array}{l}0.11^{*} \\
{[8.7]}\end{array}$ & $\begin{array}{l}18 \\
{[0.07 I]}\end{array}$ \\
\hline $5-\mathrm{HT} 2 \mathrm{C}$ & $\begin{array}{l}<10^{-2} \\
{[>1000]}\end{array}$ & $\begin{array}{l}46 \\
{[9.44]}\end{array}$ & $\begin{array}{l}12 \\
{[10.2]}\end{array}$ & $\begin{array}{l}0.4 \mid \\
{[12]}\end{array}$ & $\begin{array}{l}0.20 \\
{[48]}\end{array}$ & $\begin{array}{l}0.22 \\
{[2500]}\end{array}$ & $\begin{array}{l}0.31 \\
{[13]}\end{array}$ & $\begin{array}{l}0.043^{*}(a) \\
{[22.4]}\end{array}$ & $\begin{array}{l}37 \\
{[0.035]}\end{array}$ \\
\hline 5-HT6 & $\begin{array}{l}<10^{-2} \\
{[>1000]}\end{array}$ & $\begin{array}{l}25 \\
{[17]}\end{array}$ & $\begin{array}{l}12 \\
{[6.0]}\end{array}$ & $\begin{array}{l}<10^{-2} \\
{[>1000]}\end{array}$ & $\begin{array}{l}<10^{-2} \\
{[>1000]}\end{array}$ & $\begin{array}{l}0.30 \\
{[1864]}\end{array}$ & $\begin{array}{l}0.066 \\
{[61]}\end{array}$ & $\begin{array}{l}<10^{-2} \\
{[642]}\end{array}$ & $\begin{array}{l}52 \\
{[0.25]}\end{array}$ \\
\hline
\end{tabular}

Notes: Values indicate drug affinity for the receptor expressed relative to dopamine $\mathrm{D}_{2}$ receptor affinity, calculated $\left(\mathrm{D}_{2} \mathrm{Ki} \div \mathrm{receptor} \mathrm{Ki}\right)$; receptor $\mathrm{Ki}[\mathrm{nM}$ ] is included in square brackets below the relative affinity value. Affinity values approaching unity and above (shown in bold type) indicate the likelihood of substantial receptor occupancy at normal clinical doses.

are a class of agents that have become the most widely used to treat a variety of psychoses because of their superiority with regard to EPS. The major concern regarding the safety of the atypical antipsychotics is related to their propensity to induce weight gain and alter glucose and lipid metabolism. Their main clinical advantage beyond low EPS is their ability to improve cognition (to some extent), which is one of the key deficits in schizophrenia. Further study is needed to define their mechanism of action, particularly with regard to long-term effects on neuronal plasticity and survival. Several studies have found that amisulpride and risperidone are better tolerated than haloperidol with regard to EPS. ${ }^{33,34}$ Weight gain was also shown to be significantly greater with risperidone than with amisulpride ( $1.4 \mathrm{~kg}$ versus $0.4 \mathrm{~kg}, P=0.026) .{ }^{35}$

In a six-month treatment period, significantly fewer amisulpride-treated patients presented a weight increase of $7 \%$ or higher than that of baseline compared with those receiving risperidone (18\% versus 34\%). ${ }^{36}$ Additional evidence for decreased levels of weight gain in amisulpride-treated patients relative to olanzapine-treated patients comes from both an eight-week study (weight gain in the olanzapine versus the amisulpride group $2.7+3.9 \mathrm{~kg}$ versus $0.9+3.2 \mathrm{~kg}$, respectively) and a six-month study (weight gain in the olanzapine versus the amisulpride group $3.9 \mathrm{~kg}+5.3$ versus $1.6+4.9 \mathrm{~kg}$, respectively). ${ }^{37,38}$ Recently, a meta-analysis of all randomized and double-blind studies demonstrated that amisulpride treatment was significantly associated with relatively low weight gain. ${ }^{39}$ Collectively, these findings suggest that amisulpride is an atypical antipsychotic drug with a lower risk of weight gain. Both amisulpride and ziprasidone were preferred to olanzapine in patients who had recently experienced weight gain. ${ }^{40,41}$ This makes sense because second-generation antipsychotics do not appear to differ regarding efficacy, but both amisulpride and ziprasidone have been shown to cause less weight gain than other compounds. ${ }^{38,42,43}$

During the treatment course, the amisulpride-treated patients showed significantly decreased fasting triglyceride, total cholesterol, glucose, and insulin resistance levels, decreased diastolic blood pressure and pulse rate, and a significant increase in high-density lipoprotein cholesterol levels after switching to amisulpride (all with a $P<0.05$ ). The prevalence of metabolic syndrome in amisulpride-treated patients also decreased significantly from $65.2 \%$ to $30.4 \%$ (McNemar test, $P<0.0005$ ). These findings suggest that switching to amisulpride could be an effective treatment of overweight or obese psychiatric patients treated previously with other second-generation antipsychotics. ${ }^{44}$

In addition to weight reduction, this study showed that the lipid profiles in these overweight or obese patients also improved significantly. A growing body of evidence indicates that use of some atypical antipsychotics, including clozapine 
and olanzapine, may be linked to impairment in some healthrelated lipid indices. For instance, in a prospective study, schizophrenia patients treated with olanzapine and clozapine for four weeks showed significantly elevated triglyceride and total cholesterol levels and decreased high-density lipoprotein cholesterol levels. $^{45}$

\section{Correlation between pharmacological profile and effects of amisulpride}

Amisulpride is a unique atypical antipsychotic that selectively blocks $\mathrm{D}_{2}$ and $\mathrm{D}_{3}$ receptors presynaptically in the frontal cortex, possibly enhancing dopaminergic transmission, and postsynaptically in the limbic areas, possibly reducing it. Thus, dopaminergic overactivity in the frontal cortex and underactivity in the limbic areas, can be treated simultaneously, alleviating both positive and negative symptoms of schizophrenia, respectively. ${ }^{46}$ Additionally, the finding that amisulpride is a highly effective antidepressant via antagonism at 5- $\mathrm{HT}_{7}$ receptors would make its mechanism of action a unique one relative to other approved antidepressant drugs, and supports the development and/or testing of more selective $5-\mathrm{HT}_{7}$ receptor antagonists to treat depression in humans, ${ }^{16}$ including their effects on negative symptoms, cognitive dysfunction, mood, morbidity and mortality, work and social function, quality of life, and family and societal burden.

Other studies have demonstrated superiority over other antipsychotic agents, such as the atypical risperidone, in terms of social interactions and performance, as well as in terms of relevance of the therapeutic effect observed. In addition to low levels of EPS, as with all atypicals, amisulpride also shows a low incidence of side effects, such as weight gain, that may contribute to improved compliance and enhanced long-term efficacy. ${ }^{46}$

\section{Quality of life, patient satisfaction, acceptability, and adherence}

Schizophrenia is a chronic disorder that results in significant social, psychologic, and occupational dysfunction. Not surprisingly, schizophrenic patients score very poorly on subjective and objective measures of quality of life, even when compared with patients with other chronic psychiatric conditions, such as depression or anxiety disorders, and longterm functional impairment is very frequent. ${ }^{47}$

Quality of life measures are especially important when treating patients with chronic conditions, such as schizophrenia, which significantly impair their way of life. Every aspect of everyday life is affected, including where they live
Table 3 Quality of life

\begin{tabular}{|c|c|c|c|c|}
\hline & $\begin{array}{l}\text { Number } \\
\text { of studies }\end{array}$ & $\begin{array}{l}\text { Number of } \\
\text { participants }\end{array}$ & $\begin{array}{l}\text { Hedges' g } \\
(95 \% \mathrm{Cl})\end{array}$ & $P$ value \\
\hline Amisulpride & I & 194 & $\begin{array}{l}-0.31 \\
(-0.60 \text { to }-0.03)\end{array}$ & 0.030 \\
\hline Aripiprazole & I & 206 & $\begin{array}{l}0.06 \\
(-0.22 \text { to } 0.33)\end{array}$ & 0.683 \\
\hline Clozapine & 1 & 311 & $\begin{array}{l}-0.24 \\
(-0.46 \text { to }-0.01)\end{array}$ & 0.039 \\
\hline Olanzapine & 5 & 1450 & $\begin{array}{l}-0.07 \\
(-0.23 \text { to } 0.09)\end{array}$ & 0.398 \\
\hline Quetiapine & 2 & 166 & $\begin{array}{l}0.12 \\
(-0.18 \text { to } 0.43)\end{array}$ & 0.432 \\
\hline Risperidone & 4 & 330 & $\begin{array}{l}-0.02 \\
(-0.23 \text { to } 0.20)\end{array}$ & 0.887 \\
\hline Sertindole & I & 105 & $\begin{array}{l}-0.44 \\
(-0.83 \text { to }-0.05)\end{array}$ & 0.027 \\
\hline Ziprasidone & I & 72 & $\begin{array}{l}0.03 \\
(-0.43 \text { to } 0.49)\end{array}$ & 0.905 \\
\hline
\end{tabular}

Notes: Quality of life was reported in only 16 studies. Only amisulpride, clozapine, and sertindole were better than first-generation antipsychotic drugs. In three further olanzapine studies, no significant difference was reported for the related idea of patients' attitude towards treatment $(n=171,-0.36,95 \%$ confidence interval $(\mathrm{Cl})$ : $-0.90-0.21 ; P=0.21$. Data are Hedge's $g(95 \% \mathrm{Cl})$ or relative risk $(95 \% \mathrm{Cl})$.

and work, what activities they can perform, and how they interact with other people. Ideally, schizophrenia treatment should protect against relapse, which then becomes the foundation for improvements in quality of life and level of functioning. ${ }^{48}$

The atypical antipsychotics lack many of the problems associated with traditional treatments, and evidence suggests that they may be associated with a higher subjective quality of life (Table 3). ${ }^{49}$ However, the atypical antipsychotics may also differ from each other on a whole range of factors. Amisulpride has a good safety and tolerability profile, with fewer EPS than the conventional antipsychotics and a low incidence of anticholinergic side effects. As for other antipsychotics, corrected QT warnings are stated on the labeling for some countries, even though postmarketing surveillance for amisulpride shows no cause for concern. ${ }^{50}$

Improvement in quality of life and social functioning, with consequent reintegration into society, is clearly a major goal of treatment for schizophrenia. The improved safety and tolerability profile of the atypical antipsychotics, combined with their benefits on negative symptoms and cognitive impairment, should help achieve this aim. ${ }^{51}$ The atypical antipsychotic, amisulpride, has an improved safety and tolerability profile, and has been shown to be significantly more effective than placebo and haloperidol on a number of quality of life and social functioning scales, including the Global Assessment of Functioning, the Quality of Life Scale, 
the Functional Status Questionnaire, and the Psychosocial Aptitude Rating Scale. ${ }^{50}$

\section{Conclusion}

In conclusion, amisulpride, in addition to its proven clinical efficacy, may help reintegration of the schizophrenic patient back into social inclusion. The negative symptoms of schizophrenia are characterized by poverty of speech, blunted affect, lack of initiative, poor motivation, and a general slowness and underactivity, all of which result in social withdrawal. This may reflect the fact that new-generation antipsychotics have more distinct differences in their safety and tolerability profiles than in their efficacy characteristics. Although this knowledge helps to guide clinicians in drug choice, the translation of clinical trial findings into individual patient needs remains a daunting challenge. Cognitive impairment also plays a role in occupational and social functioning. Recent data indicate that, in the case of the atypical antipsychotic amisulpride, these properties can be translated into a better quality of life, and enhanced social functioning and reintegration into society.

\section{Disclosure}

The authors report no conflicts of interest in this work.

\section{References}

1. Lahti AC, Weiler MA, Holcomb HH, Tamminga CA, Carpenter WT, McMahon R. Correlations between rCBF and symptoms in two independent cohorts of drug-free patients with schizophrenia. Neuropsychopharmacology. 2006;31:221-230.

2. Meltzer HY. What's atypical about atypical antipsychotic drugs? Curr Opin Pharmacol. 2004;4:53-57.

3. Robertson GS, Matsumura H, Fibiger HC. Induction patterns of fos-like immunoreactivity in the forebrain as predictors of atypical antipsychotic activity. J Pharmacol Exp Ther. 1994;271:1058-1066.

4. de Oliveira IR, Ribeiro MG, Fregoneze JB, de Sena EP, de Castro E, Silva E. Regional c-fos expression in rat brain may predict antipsychotic therapeutic window. J Clin Psychopharmacol. 2000;20:705-706.

5. Geddes J, Freemantle N, Harrison P, Bebbington P. Atypical antipsychotics in the treatment of schizophrenia: Systematic overview and meta-regression analysis. BMJ. 2000;321:1371-1376.

6. Kapur S. Psychosis as a state of aberrant salience: A framework linking biology, phenomenology, and pharmacology in schizophrenia. Am J Psychiatry. 2003;160:13-23.

7. Meltzer HY. The role of serotonin in antipsychotic drug action. Neuropsychopharmacology. 1999;21:106-115.

8. Schoemaker H, Claustre Y, Fage D, et al. Neurochemical characteristics of amisulpride, an atypical dopamine D2/D3 receptor antagonist with both presynaptic and limbic selectivity. J Pharmacol Exp Ther. 1997; 280:83-97.

9. Leucht S, Pitschel-Walz G, Engel RR, Kissling W. Amisulpride, an unusual "atypical" antipsychotic: A meta-analysis of randomized controlled trials. Am J Psychiatry. 2002;159:180-190.

10. Davis JM, Chen N, Glick ID. A meta-analysis of the efficacy of second-generation antipsychotics. Arch Gen Psychiatry. 2003;6: $553-564$.
11. de Oliveira IR, Miranda-Scippa AM, de Sena EP, et al. Risperidone versus haloperidol in the treatment of schizophrenia: a meta-analysis comparing their efficacy and safety. J Clin Pharm Ther. 1996;21:349-358.

12. Leucht S, Corves C, Arbter D, Engel RR, Li C, Davis JM. Secondgeneration versus first-generation antipsychotic drugs for schizophrenia: A meta-analysis. Lancet. 2009;373:31-41.

13. Wetzel H, Grunder G, Hillert A, et al. Amisulpride versus flupentixol in schizophrenia with predominantly positive symptomatology - a double-blind controlled study comparing a selective D2-like antagonist to a mixed D1-/D2-like antagonist. The Amisulpride Study Group. Psychopharmacology (Berl). 1998;137:223-232.

14. Sleight AJ, Carolo C, Petit N, Zwingelstein C, Bourson A. Identification of 5-hydroxytryptamine7 receptor binding sites in rat hypothalamus: Sensitivity to chronic antidepressant treatment. Mol Pharmacol. 1995; 47:99-103.

15. Mullins UL, Gianutsos G, Eison AS. Effects of antidepressants on 5-HT7 receptor regulation in the rat hypothalamus. Neuropsychopharmacology. 1999;21:352-367.

16. Abbas AI, Hedlund PB, Huang XP, Tran TB, Meltzer HY, Roth BL. Amisulpride is a potent 5-HT7 antagonist: Relevance for antidepressant actions in vivo. Psychopharmacology (Berl). 2009;205: 119-128.

17. Kvachnina E, Liu G, Dityatev A, et al. 5-HT7 receptor is coupled to $\mathrm{G}$ alpha subunits of heterotrimeric G12-protein to regulate gene transcription and neuronal morphology. J Neurosci. 2005;25: 7821-7830

18. Dalmau A, Bergman B, Brismar B. Somatic morbidity in schizophrenia a case control study. Public Health. 1997;111:393-397.

19. Harris EC, Barraclough B. Excess mortality of mental disorder. $\mathrm{Br} J$ Psychiatry.1998;173:11-53.

20. Kurzthaler I, Fleischhacker WW. The clinical implications of weight gain in schizophrenia. J Clin Psychiatry. 2001;62 Suppl 7:32-37.

21. Allison DB, Casey DE. Antipsychotic-induced weight gain: A review of the literature. J Clin Psychiatry. 2001;62 Suppl 7:22-31.

22. Allison DB, Mackell JA, McDonnell DD. The impact of weight gain on quality of life among persons with schizophrenia. Psychiatr Serv. 2003;54:565-567.

23. Werneke U, Taylor D, Sanders TA. Options for pharmacological management of obesity in patients treated with atypical antipsychotics. Int Clin Psychopharmacol. 2002;17:145-160.

24. Weiden PJ, Mackell JA, McDonnell DD. Obesity as a risk factor for antipsychotic noncompliance. Schizophr Res. 2004;66:51-57.

25. de Hert MA, van WR, van ED, et al. Prevalence of the metabolic syndrome in patients with schizophrenia treated with antipsychotic medication. Schizophr Res. 2006;83:87-93.

26. McEvoy JP, Meyer JM, Goff DC, et al. Prevalence of the metabolic syndrome in patients with schizophrenia: Baseline results from the Clinical Antipsychotic Trials of Intervention Effectiveness (CATIE) schizophrenia trial and comparison with national estimates from NHANES III. Schizophr Res. 2005;80:19-32.

27. Bai YM, Chen JY, Yang WS, et al. Adiponectin as a potential biomarker for the metabolic syndrome in Chinese patients taking clozapine for schizophrenia. J Clin Psychiatry. 2007;68:1834-1839.

28. Buis W. Patient's opinions concerning side effects of neuroleptics. Am J Psychiatry. 1992;149:844-845.

29. Casey D. Side effect profiles of new antipsychotic agents. J Clin Psychiatry. 1996;57:40-45.

30. Kerwin RW. The new atypical antipsychotics. A lack of extra pyramidal side-effects and new routes in schizophrenia research. Br J Psychiatry. 1994;164:141-148

31. Kane JM. Clozapine in the treatment of schizophrenia. Encephale. 1996;22:7-11.

32. Lieberman JA, Stroup TS, McEvoy JP, et al. Clinical antipsychotic trials of intervention effectiveness (CATIE) investigators. Effectiveness of antipsychotic drugs in patients with chronic schizophrenia. $N$ Engl J Med. 2005;353:1209-1203. 
33. Colonna L, Saleem P, Dondey-Nouvel L, Rein W. Long term safety and efficacy of amisulpride in subchronic or chronic schizophrenia. Int Clin Psychopharmacol. 2000;15:13-22.

34. Carrière $P$, Bonhomme D, Lemperière T. Amisulpride has a superior benefit/risk profile to haloperidol in schizophrenia. Eur Psychiatry. 2000;15:321-329.

35. Peuskens J, Bech P, Möller HJ, Bale R, Fleurot O, Rein W. Amisulpride versus risperidone in the treatment of acute exacerbations of schizophrenia. Psychiatry Res. 1999;88:107-117.

36. Sechter D, Peuskens J, Fleurot O, et al. Amisulpride vs risperidone in chronic schizophrenia: Results of a 6-month double-blind study. Neuropsychopharmacology. 2002;27:1071-1081.

37. Martin S, Ljo H, Peuskens J, et al. A double-blind, randomized comparative trial of amisulpride versus olanzapine in the treatment of schizophrenia: Short-term results at two months. Curr Med Res Opin. 2002; 18:355-362.

38. Mortimer A, Martin S, Loo H, et al. A double-blind, randomized comparative trial of amisulpride versus olanzapine for 6 months in the treatment of schizophrenia. Int Clin Psychopharmacol. 2004;19: 63-69.

39. Leucht S, Wagenpfeil S, Hamann J, et al. Amisulpride is an atypical antipsychotic associated with low weight gain. Psychopharmacology (Berl). 2004;173:112-115.

40. Tandon R. Section of Pharmacopsychiatry; World Psychiatric Association. World Psychiatric Association Pharmacopsychiatry Section. Schizophr Res. 2008:100;20-38.

41. Motlová L. Are there any differences in the efficacy among second generation antipsychotics in the treatment of schizophrenia and related disorders? Ann Clin Psychiatry. 2007;19:133-143.

42. American Psychiatric Association, 2008. Practice guidelines for the treatment of patients with schizophrenia. Available from: http://www. psychiatryonline.com/pracGuide/pracGuideChapToc_6.aspx. Accessed Jul 29, 2010
43. Newcomer JW. Second-generation (atypical) antipsychotics and metabolic effects: A comprehensive literature review. CNS Drugs. 2005:19 Suppl 1:1-93.

44. Lin CC, Bai YM, Wang YC, et al. Improved body weight and metabolic outcomes in overweight or obese psychiatric patients switched to amisulpride from other atypical antipsychotics. J Clin Psychopharmacol. 2009;29:529-536.

45. Rettenbacher MA, Ebenbichler C, Hofer A, et al. Early changes of plasma lipids during treatment with atypical antipsychotics. Int Clin Psychopharmacol. 2006;21:369-372.

46. Lecrubier Y. Amisulpride: Progress and outcomes. Curr Med Res Opin. 2002;18 Suppl 3:18-22.

47. Saleem P, Olié JP, Loo H. Social functioning and quality of life in the schizophrenic patient: Advantages of amisulpride. Int Clin Psychopharmacol. 2002;17:1-8.

48. Weiden P, Aquila R, Standard J. Atypical antipsychotic drugs and long-term outcome in schizophrenia. J Clin Psychiatry. 1996;57 Suppl 11:53-60.

49. Franz M, Lis S, Pluddemann K, Gallhofer B. Conventional versus atypical neuroleptics: Subjective quality of life in schizophrenic patients. Br J Psychiatry. 1997;170:422-425.

50. Coulouvrat C, Dondey-Nouvel L. Safety of amisulpride (Solian): A review of 11 clinical studies. Int Clin Psychopharmacol. 1999;14: 209-218.

51. de Oliveira IR, Juruena MF. Treatment of psychosis: 30 years of progress. J Clin Pharm Ther. 2006;31:523-534.
Drug, Healthcare and Patient Safety

\section{Publish your work in this journal}

Drug, Healthcare and Patient Safety is an international, peer-reviewed open-access journal exploring patient safety issues in the healthcare continuum from diagnostic and screening interventions through to treatment, drug therapy and surgery. The journal is characterized by the rapid reporting of reviews, original research, clinical, epidemiological and

\section{Dovepress}

post-marketing surveillance studies, risk management, health literacy and educational programs across all areas of healthcare delivery. The manuscript management system is completely online and includes a very quick and fair peer-review system. Visit http://www.dovepress.com/ testimonials.php to read real quotes from published authors. 